
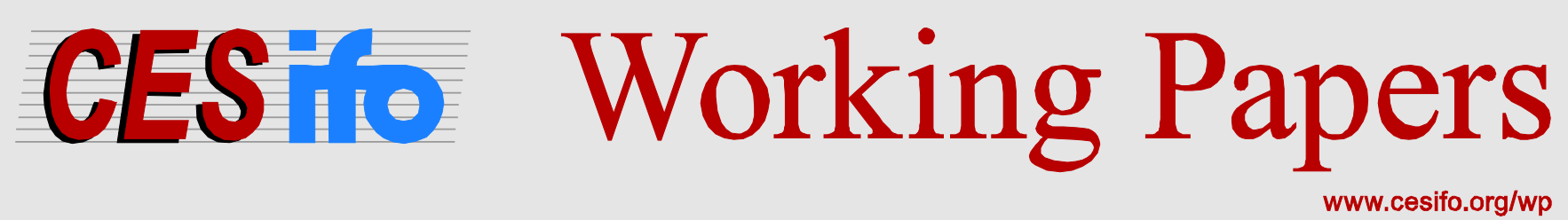

\title{
Foreign Aid in Areas of Limited Statehood
}

\author{
Axel Dreher \\ Valentin Lang \\ Sebastian Ziaja
}

CESIFO WORKING PAPER NO. 6340

CATEgory 2: Public CHOICE

FEBRUARY 2017

An electronic version of the paper may be downloaded

- from the SSRN website:

- from the RePEc website:

- from the CESifo website:

WWW.SSRN.com

Www.RePEc.org

www.CESifo-group.org/wp 


\title{
Foreign Aid in Areas of Limited Statehood
}

\begin{abstract}
We review the aid effectiveness literature to assess whether foreign aid given to areas of limited statehood can be expected to promote economic and social outcomes in the recipient country. We distinguish different types of aid, motives for granting it, recipient country policies and characteristics, and modalities by which aid is delivered, as these factors have been argued to influence the effectiveness of aid. In short, aid is most likely to be successful if given for nonstrategic motives, and if given to recipient countries with "good" policies and democratic institutions. Fragmented aid and aid amounts that exceed the absorptive capacity of the recipient reduce the effectiveness of aid. We then compare these properties between recipients most affected by limited statehood and those least affected. This allows us to assess the relative effectiveness of aid in countries with areas of limited statehood. We conclude that on average aid given there is less likely to be effective than elsewhere.
\end{abstract}

JEL-Codes: F350, H770, O470, O570, P260.

Keywords: aid effectiveness, fragile states, limited statehood.

\author{
Axel Dreher \\ Heidelberg University \\ Alfred-Weber-Institute for Economics \\ Bergheimer Strasse 58 \\ Germany - 69115 Heidelberg \\ mail@axel-dreher.de
}

Valentin Lang

Heidelberg University

Alfred-Weber-Institute for Economics

Bergheimer Strasse 58

Germany - 69115 Heidelberg

valentin.lang@awi.uni-heidelberg.de

\author{
Sebastian Ziaja \\ Heidelberg University \\ Research Center for Distributional Conflict \\ and Globalization \\ Bergheimer Strasse 58 \\ Germany - 69115 Heidelberg \\ ziaja@uni-heidelberg.de
}

February 2017

We thank Tanja Börzel, Anke Draude, Thomas Risse, and other participants at the Author's Workshop for the Oxford Handbook of Governance and Limited Statehood at FU Berlin (2016) for helpful comments and Jamie Parsons for proof-reading 


\section{Introduction}

A large literature in economics and political science provides statistical estimates testing whether and under which conditions foreign aid affects economic and social development. ${ }^{1}$ With respect to economic growth, some papers find aid to be effective in raising growth in recipient countries (Clemens et al. 2012, Galiani et al. 2016), while others show aid to be ineffective (Rajan and Subramanian 2008, Dreher and Langlotz 2015). Still others find that the effectiveness of aid in promoting growth is conditional on policies and institutions in donor or recipient countries, or on the motives guiding the giving of aid (Dreher et al. 2016, Minasyan et al. 2016). An indirect effect of aid on social and economic development may operate through an improvement in the recipients' policies and institutions. However, results are equally mixed regarding the effect of aid on economic policies (Dreher and Gehring 2012), economic infrastructure (Donaubauer et al. 2016, Donaubauer and Nunnenkamp 2016) as well as democracy and institutional quality (Rajan and Subramanian 2007, Djankov et al. 2008, Baliamoune-Lutz and Mavrotas 2009, Askarov and Doucouliagos 2013, Kersting and Kilby 2014). Sectoral outcomes have also received attention. While the evidence regarding the net effect of aid on education is, at least to some extent, positive (Dreher et al. 2008a, Christensen et al. 2011, Birchler and Michaelowa 2016), whether and to what extent aid is effective in improving health conditions is more disputed (Williamson 2008, Nunnenkamp and Öhler 2011).

Most of the studies in the aid effectiveness literature focus on all aid-receiving countries in the world, employing four- or five-year averages over a period of around 30 years. Results are

${ }^{1}$ The Development Assistance Committee (DAC) of the OECD defines Official Development Assistance (ODA) as "[g]rants or loans to [developing] countries and territories [...] and to multilateral agencies which are: (a) undertaken by the official sector; (b) with promotion of economic development and welfare as the main objective; (c) at concessional financial terms (if a loan, having a grant element of at least 25 per cent)." (OECD DAC glossary, available at http://www.oecd.org/dac/dac-glossary.htm). The bulk of ODA is given by bilateral donors, followed by multilateral organizations and aid channeled via Non-Governmental Organizations (NGOs). On average, DAC donors provided 0.3 percent of their GNI in aid in 2015 - way below the 0.7 percent target set by the United Nations. 
then drawn based on a sample of about 400 observations. In this paper, we focus on those countries that are most severely affected by limited statehood, or fragile states. While the conceptual literature on areas of limited statehood emphasizes subnational dynamics, the empirical aid literature has only recently begun to focus on the subnational level (e.g., Briggs 2014, Dreher and Lohmann 2015, Dreher et al. 2016). We thus retain the methodological focus on the nation-state.

The number of countries with severely limited statehood is too low to statistically investigate the effect of aid on developmental outcomes in a rigorous setting. Therefore, in this paper we offer an alternative route to assess the effects of aid in these settings: The descriptive statistics we provide show that countries with areas of limited statehood differ from other aid receiving countries in ways that, according to the aid effectiveness literature, interact with the effectiveness of aid for social and economic development. Based on the literature on aid effectiveness at large, we can thus assess the expected effects of aid in areas of limited statehood.

To this end, we first comment on the literature on the effectiveness of general aid in section 2 , and turn to a particular view on the conditions under which aid has empirically been shown to be more or less effective compared to average aid in section 3. In section 4 , we then discuss these conditions with respect to the characteristics of areas of limited statehood, and the implications for the effectiveness of aid there. The final section concludes.

\section{Does aid affect economic and social development?}

Most of the earlier aid literature based its inferences on conditional correlations between aid and development. It was thus not able to determine whether the relationship was causal. Much of the more recent literature attempts to remedy this shortcoming with internal or external instruments for aid. To identify the causal effect of aid on development these scholars rely on the assumption that the only channel that explains the correlation of their instrumental variables with development outcomes is aid (the exclusion restriction). Three strategies are particularly prominent in the recent literature (Dreher et al. 2016). First, researchers employ internal instruments (lagged aid levels and differences) in the context of difference or system generalized 
method of moments (GMM) estimations. Second, they use external instruments for aid that mainly rely on the recipient country's population size (see Bazzi and Clemens 2013). Third, they base the analysis on instruments that proxy for the geopolitical importance of a recipient country to the donor, implicitly or explicitly generalizing the Local Average Treatment Effect (LATE) that these instruments identify to be representative of all aid, rather than political aid exclusively. The first two estimation strategies violate the exclusion restriction. Clearly, population size and lagged aid can affect growth through channels other than contemporaneous aid. The third strategy requires the assumption that the effects of aid are independent of the donors' motives for granting it. This might be reasonable. Donors who have already committed a certain amount of aid might be motivated to achieve developmental outcomes, independent of their reasons for giving aid in the first place (Rajan and Subramanian 2008). Kilby and Dreher (2010) and Dreher et al. (2016) however provide evidence that donor motives influence the effectiveness of aid in promoting growth. Estimated coefficients using political variables as instruments for aid thus estimate the effect of politically motivated aid, and constitute a lower bound for the effect of all aid.

The concerns regarding the most prominent identification strategies used in the aid effectiveness literature raise doubts regarding the viability of the results of studies using them. ${ }^{2}$ In spite of the large number of papers in this literature, we thus think that it is fair to say that no consensus has emerged about the effectiveness of aid. ${ }^{3}$ The literature is plagued by a number of problems that contribute to this lack of consensus. Arguably most prevalent among these problems is the lack of an accepted identification strategy, giving rise to a large number of conditional correlations reported in this literature, but a dearth of carefully identified causal effects. What is more, data on aid and growth are noisy, which is why measurement error makes the identification of a causal effect difficult. In particular, growth statistics for many low-income

${ }^{2}$ A couple of recent papers suggest more plausible instruments (Werker et al. 2009, Nunn and Qian 2014, Dreher and Lohmann 2015, Dreher and Langlotz 2015, Galiani et al. 2016, Dreher et al. 2016). See Dreher and Langlotz (2015) for a discussion.

${ }^{3}$ See Werker (2012) and Doucouliagos (2016) for recent reviews. 
countries on the African continent have been shown to be unreliable (Jerven 2013). What is more, the number of available observations is low. Most of the papers in the aid effectiveness literature thus lack statistical power. These regressions would not find an effect of aid even if it was there (Ioannidis et al. 2016). Finally, a large number of different specifications and instrumental variables are a priori equally reasonable, but results depend on their choice.

Some words of caution are thus in order. Our summary as to the types of aid that are more or less effective is based on a literature plagued by the problems outlined above, among others. This shaky base of evidence is the best we have at our disposal. As a consequence, the evidence summarized here and the recommendations we derive from them are preliminary rather than definitive. With this caveat in mind, we turn to the effects of aid that are conditional on the characteristics of aid, donors, recipients, or their combination.

\section{Conditional aid effectiveness?}

The papers in the so-called "conditional aid effectiveness literature" are too numerous for this paper to cover them all (Doucouliagos and Paldam 2009 give an overview). It has been argued and shown that the effectiveness of aid depends on recipient country policies and institutions, and the motives and characteristics of the donor. The characteristics of aid and the modalities of its delivery have also been highlighted as important determinants of aid effectiveness.

The most prominent approach in the conditional aid effectiveness literature is the socalled "good policy" model proposed in Burnside and Dollar (2000), and further investigated in a substantial number of follow-up studies (see Doucouliagos and Paldam 2009). According to this model, the effectiveness of aid depends on the quality of policies - low budget deficits and inflation, as well as openness to trade - in the country receiving the aid. Burnside and Dollar show that aid increases economic growth when given to recipients scoring high on the "goodpolicy" index, but not when it is disbursed to others. While the lack of robustness of these results has frequently been demonstrated (Easterly et al. 2004, Rajan and Subramanian 2008, Dreher and Langlotz 2015, among many others), the notion that aid is more effective when given to recipients 
with "good" economic policies is intuitive and continues to be prominent among pundits and donors of aid alike.

Building on Burnside and Dollar's results, subsequent studies have examined whether the recipients' policies and institutions in more general terms change the effect of aid on growth and human development. Aid effectiveness has been reported to improve with institutional quality as measured by the World Bank's Country Policy and Institutional Assessment (Collier and Dollar 2002), political stability (Chauvet and Guillaumont 2003), advantageous geography (Dalgaard et al. 2004), and democracy (Svensson 1999, Kosack 2003).

The level of democracy in the recipient country appears to particularly influence the effect of aid on governance and political institutions. The recent evidence suggests that while aid increases the chances of survival for political leaders (Bueno de Mesquita and Smith 2010, Kono and Montinola 2009), it also makes democracies more democratic and autocracies more autocratic (Ahmed 2012, Dutta et al. 2013). Aid appears to support current leaders and "amplify" the existing political institutions in recipient countries. To the extent that democratic institutions promote social and economic development, the indirect effect of aid on development through institutions is thus positive in democratic countries and potentially harmful in autocracies.

Donor policies and motives, rather than those of the recipients, have also been shown to matter for the effectiveness of aid. ${ }^{4}$ Aid that is given for reasons other than social and economic development in recipient countries is less effective than aid that is intended for this purpose (Dreher et al. 2016). If donors are motivated by pure self-interest, their allocation decision does not depend on the way the recipient uses the aid. A politically motivated allocation of aid may result in the approval of lower-quality aid projects in favored countries instead of more promising projects elsewhere. Donors with such motives may also fail to include growth-promoting policy conditions or waive them in cases of non-compliance. Political favoritism might thus allow

${ }^{4}$ More recently the literature started paying attention to donor-recipient-specific characteristics. For example, Dreher et al. (2015) show that aid is more effective when donors and recipients of aid are more closely aligned in terms of their political ideology. Minasyan (2016) obtains similar results for donors and recipients who share a similar cultural understanding. 
projects to be pursued where important preconditions are not met or might reduce the time and resources devoted to the preparation of a project. The recipient might choose to use disbursed aid for purposes other than development if punishment for non-compliance is less likely, resulting, on average, in inferior outcomes (Dreher et al. 2016). To test whether aid is indeed less effective when given for geopolitical reasons, Dreher et al. (2016) compare the growth effects of aid that has been committed while the recipient country was a temporary member of the United Nations Security Council (UNSC) to the effects of aid countries receive at other times. They find that aid given for political reasons is substantially less effective compared to aid given for other motives. ${ }^{5}$

Aid by so-called "good" donors has been shown to be more effective compared to aid given by the average donor. Minasyan et al. (2016) find that aid from donors that rank higher on the Center for Global Development's index of donor performance (Roodman 2012) has a stronger effect on recipient growth compared to aid from donors on the lower ranks. ${ }^{6}$ Minoiu and Reddy (2010) focus on donors with large aid budgets and no apparent strategic motives in the allocation of their aid - Denmark, Finland, Norway, Sweden and the Netherlands. Bermeo (2011) investigates aid from democracies. She finds that aid from authoritarian countries reduces recipient democracy, while aid from democracies promotes democracy.

Multilateral donors and NGOs are also frequently expected to be "better" donors than bilateral ones for several reasons, including their aid decisions being less dominated by political considerations and more poverty-oriented (Riddell et al. 1995, Headey 2008, Milner and Tingley 2013, Findley et al. 2016). There is substantial evidence, however, that - due to the influence of large shareholders - political interests also affect the allocation of multilateral aid (Dreher et al.

${ }^{5}$ Dreher et al. (2013) find similar evidence regarding the quality of World Bank projects. This result fits the evidence reported by Kilby (2013), who focuses on World Bank loans and finds shorter preparation periods for aid projects in countries that are geopolitically important for the Bank's major shareholders. In a followup study, he finds that longer preparation time increases the likelihood that development will have favorable outcomes (Kilby 2015). On similar evidence regarding infant mortality, see Girod (2012).

${ }^{6}$ Criteria used in the ranking include "a penalty for tying aid; a discounting system that favors aid to poorer, better-governed recipients; and a penalty for "project proliferation"”" (Roodman 2012). 
2009a, 2009b). Despite this, political interests in multilateral aid giving seem less prevalent than in bilateral aid (Kuziemko and Werker 2006).

This may be one reason why a number of papers have shown multilateral aid to be more effective than bilateral aid. Among them, Headey (2008) and Girod (2008) find multilateral aid to be effective in raising economic growth, and both attribute this to the absence of political motives. Cashel-Cordo and Craig (1990) show multilateral aid to be more effective in raising recipient government development expenditures; Yontcheva and Masud (2005) find the same regarding health outcomes and overall human development. The meta-analysis in Askarov and Doucouliagos (2013), which focuses on institutional quality in recipient countries, generally supports this result. ${ }^{7}$

The notion that aid channeled through NGOs is superior to that given directly by bilateral donors has long been an "article of faith" (Tendler 1982, Riddell et al. 1995). Critics, however, already suspected in the 1990s that NGOs might be less than fully autonomous, with relations to state agencies being "too close for comfort" (Edwards and Hulme 1996), resulting in NGO aid also being dominated by political considerations. Indeed, Dreher et al. (2012a, 2012b) and Koch et al. (2009) find that political interests of the NGOs" "backdonor" affect the allocation of NGO aid. Nevertheless, geopolitical motivations are likely to be less important for NGO aid as compared to bilateral aid as at least some degree of autonomy remains and a focus on developmental outcomes is thus more likely. Recent work shifted attention to the specific circumstances under which aid is channeled through NGOs. Dietrich (2013) and Acht et al. (2015) show that in poorly-governed recipient countries donors bypass recipient governments and deliver more aid through NGOs and other non-state actors than through traditional governmentto-government channels. These results suggest that donors expect aid channeled through NGOs to be more effective than other aid where governance is poor.

${ }^{7}$ Others however disagree (e.g., Rajan and Subramanian 2008). Dreher and Lohmann (2015) find no effect of World Bank aid on development at the subnational level. See Biscaye et al. (2015) for a detailed review. 
Finally, the conditional aid effectiveness literature has also considered the characteristics of aid itself, rather than those of the donors or the recipients. Budget aid has been suggested to be more effective than project aid, and untied aid is generally thought to be superior to tied aid. Fragmented aid and aid exceeding the recipient country's absorptive capacity are considered harmful. We discuss them in turn. ${ }^{8}$

Untied aid and budget aid are sometimes considered more effective (compared to tied aid and project aid) as these types of aid give recipients more control. Their execution is thus less dominated by political influences (Milner 2006). ${ }^{9}$ The formal model in Jelovac and Vandeninden (2008) suggests that budget aid is always preferable over project aid in improving development outcomes. However, Dreher et al. (2008b) show that budget support - and to some extent untied aid - are more strongly associated with donor-recipient political ties, as they are considered more valuable than project aid and are thus used more often to "reward" allies. Selaya and Thiele (2012) show that budget support can undermine governance. Particularly in weak institutional environments, the effectiveness of budget aid can thus decrease. According to Radelet (2004), "in weak, failing, and poorly governed countries where governments have shown little commitment to good development policy, donors should retain a strong role in setting priorities and designing programs." The model in Dreher et al. (2017) shows that in addition to differences in preferences between the donor and the recipient, the relative important of their private information matters for whether or not budget aid is preferable over project aid. Overall, we expect budget aid to be less effective in areas of limited statehood compared to project aid. We have no clear prediction regarding tied aid.

Closely linked to this is the discussion as to whether aid fragmentation undermines its effectiveness. Receiving many aid projects from a large number of donors may increase transaction costs and overburden weak bureaucracies (Anderson 2012, Knack and Rahman 2007). Indeed, Djankov et al. (2009) and Kimura et al. (2012) show that aid fragmentation reduces the

${ }^{8}$ According to Bjørnskov (2013), reconstruction aid is most effective in raising economic growth.

${ }^{9}$ Koeberle et al. (2006) provide a detailed review. 
effectiveness of aid in promoting growth. ${ }^{10}$ According to the results in Bigsten and Tengstam (2015), international coordination, a focus of donors on fewer recipients and a shift from projectto program-based approaches would increase the effectiveness of aid to reduce poverty. Ziaja (2016) however points to a positive effect of aid fragmentation in the field of democracy assistance: when more donors are present, different interests in the recipient society are catered for, leading to more viable democratic institutions.

Among the characteristics of aid that have received most attention in the conditional aid effectiveness literature is the amount of aid received. Hadjimichael et al. (1995) were among the first to suggest that aid can work when reasonable amounts are given but becomes ineffective when the amount given exceeds the manageable range - an observation that Jensen and Paldam (2006) dubbed the "medicine model." Scholars argue that exceeding the "absorptive capacity" of recipient countries undermines aid effectiveness (Feeny and de Silva 2013). Presbitero (2016), for instance, finds that World Bank projects are less likely to be successful when implemented during the scaling-up of public investment and suggests that this indicates the presence of limits to recipients' absorptive capacity. While the meta-study by Doucouliagos and Paldam (2009) concludes that the evidence on the existence of such a "turning point" is inconclusive, a large number of studies find that there are decreasing and eventually negative returns to increasing amounts of aid. ${ }^{11}$ A recent estimate of the turning point where aid no longer contributes to raising growth is between 15\%-25\% of recipient country GDP (Clemens et al. 2012). While few countries receive aid well above this point, Feeny and McGillivray (2011) suggest that about 16 countries received aid beyond the growth-maximizing level in the 2002-2005 period. ${ }^{12}$

In summary, the literature expects aid to be more effective when given by multilateral donors, for developmental reasons, to democratic recipients with good policies and institutions,

${ }^{10}$ Gehring et al. (2015) however point to the fragility of these findings.

${ }^{11}$ Boone (1996) however finds large amounts of aid to be more rather than less effective, which he attributes to limited fungibility there.

${ }^{12}$ See Table 1 in Djankov et al. (2006) for the largest ODA recipients in recent history. 
in reasonable amounts and with an eye to avoiding fragmentation. In areas of limited statehood, we expect it to be more effective when given as project aid and via NGOs.

\section{Areas of limited statehood and the effectiveness of aid}

How well do donors achieve the goal of promoting social and economic development in areas of limited statehood? In order to answer this question, we determine which countries are most affected by limited statehood ("fragile states") and compare these to countries least affected ("non-fragile states"). We compare these groups with respect to recipient, donor, and aid characteristics that influence the effectiveness of aid.

Deriving a list of fragile states is not trivial. Ziaja (2012) provides an overview of existing approaches to quantifying state fragility. Due to conceptual and empirical deficiencies, none of these approaches promise a valid distinction between fragile and non-fragile cases for our present purpose. ${ }^{13}$ We thus construct our own measure based on Risse (2011: 4), who defines areas of limited statehood as "[...] those parts of a country in which central authorities (governments) lack the ability to implement and enforce rules and decisions or in which the legitimate monopoly over the means of violence is lacking, at least temporarily." 14 To classify states as fragile and non-

${ }^{13}$ See Grävingholt et al. (2015) for suggestions of how to better identify fragile states.

${ }^{14}$ Lee et al. (2014) build on the same concept and suggest using indicators of the monopoly of violence and of fiscal capacity to identify fragile states. They measure the monopoly of violence with two ordinal indicators from the Political Instability Task Force that attempt to quantify the extent of the territory affected by fighting during revolutionary wars (magarea) and the degree to which state functions are obstructed during adverse regime changes (magfail; Marshall et al. 2016). Fiscal capacity is measured by the efficiency of the tax administration, as measured on a one to four scale by the Institutional Profiles Database (Bertho 2013). Unfortunately, the latter variable is only available for the years 2009 and 2012. Employing only two years would severely limit the robustness of our comparison. Furthermore, the approach of the Political Instability Task Force of classifying state collapse into four separate types a priori (ethnic war, revolutionary war, genocide and adverse regime change) and coding magarea and magfail only for one type, 
fragile, we draw on two different methods of measuring limitations to statehood and consider states only to be fragile if both sources suggest this. We then compare those states to the ones considered considerably less fragile by any of the two sources, thus excluding ambiguous cases from the analysis.

Our first indicator is the Bertelsmann Transformation Index (BTI), which publishes biannual data from 2006 to 2016 for up to 129 developing countries (BTI 2016). ${ }^{15}$ We code an indicator variable for fragility that equals one if any of the indicators monopoly on the use of force and basic administration score 4 or less, on a scale ranging from 1 (worst) to 10 (best). ${ }^{16}$ These indicators constitute valid representations of the conceptual attributes, i.e., the monopoly of violence and the ability to implement rules. Nonetheless, we do not want our classification to suffer from a potential bias in this source. We thus add a second source coded by a different set of experts.

The second source is the list of "fragile situations" published by the World Bank since 2006. Countries are considered to be in fragile situations when they score 3.2 or lower on the Country Institutional and Policy Assessment (CPIA), conducted annually by the Bank to rate a country's "economic management, structural policies, policies for social inclusion and equity, and public sector management and institutions." A second, alternative criterion for the World Bank's "fragile situations" list is the presence of a United Nations peacekeeping or peacebuilding mission.

respectively, leads to somewhat surprising results (e.g., India is classified as fragile in 2012, but the Democratic Republic of Congo is not).

15 The BTI scores are largely based on data gathered in the preceding year, so we consider the 2016 edition as reflecting the status in 2015 etc. We interpolate the biannual missing observations with data from the previous year.

${ }^{16}$ A score of 4 is described by the BTI codebook (BTI 2014: 16) for the monopoly of violence as such: "The state's monopoly on the use of force is established only in key parts of the country. Large areas of the country are controlled by guerrillas, paramilitaries or clans"; for basic administration "The administrative structures of the state are extending beyond maintaining law and order, but their territorial scope and effectivity are limited." 
With the combined BTI and World Bank list, a total of 26 countries are considered fragile by both sources in at least one year within the ten years in our sample. Table 1 lists those states, as well as the first and the last year between 2006 and 2015 when they were considered fragile, and the number of years they were considered fragile in that time period. Equipped with this list we now turn to comparing fragile with non-fragile countries with regard to the properties that the literature has shown to interact with the effectiveness of aid. We discuss recipient characteristics, donor characteristics and motives, and aid characteristics in turn. 
Table 1: List of fragile states, combined BTI and World Bank approach, 2006-2015

\begin{tabular}{|c|c|c|c|}
\hline Country & First year & Last year & Number of years \\
\hline Afghanistan & 2006 & 2015 & 10 \\
\hline Angola & 2006 & 2013 & 4 \\
\hline Central African Republic & 2006 & 2015 & 10 \\
\hline Chad & 2006 & 2015 & 10 \\
\hline Congo & 2007 & 2012 & 6 \\
\hline Congo, DRC & 2006 & 2015 & 10 \\
\hline Cote d'Ivoire & 2006 & 2012 & 7 \\
\hline Eritrea & 2011 & 2015 & 5 \\
\hline Georgia & 2010 & 2010 & 1 \\
\hline Guinea & 2007 & 2012 & 6 \\
\hline Haiti & 2006 & 2015 & 10 \\
\hline Iraq & 2011 & 2015 & 5 \\
\hline Liberia & 2006 & 2012 & 7 \\
\hline Libya & 2013 & 2015 & 3 \\
\hline Mali & 2014 & 2014 & 1 \\
\hline Myanmar & 2006 & 2015 & 10 \\
\hline Nepal & 2011 & 2014 & 4 \\
\hline Nigeria & 2006 & 2006 & 1 \\
\hline Papua New Guinea & 2007 & 2010 & 3 \\
\hline Somalia & 2006 & 2015 & 10 \\
\hline South Sudan & 2013 & 2015 & 3 \\
\hline Sudan & 2006 & 2015 & 10 \\
\hline Syria & 2013 & 2015 & 3 \\
\hline Tajikistan & 2006 & 2006 & 1 \\
\hline Yemen & 2009 & 2015 & 7 \\
\hline Zimbabwe & 2007 & 2010 & 4 \\
\hline
\end{tabular}




\section{Recipient characteristics}

Figure 1 (left panel) shows that income per capita is very low in most fragile states: hardly any reach more than 2,000 USD. ${ }^{17}$ One could argue that fragile states are thus in more need of assistance, and that aid to these countries could potentially be more effective. Non-fragile states, on the other hand, are found across the whole range of incomes. It is worthwhile to note that very poor states can be non-fragile.
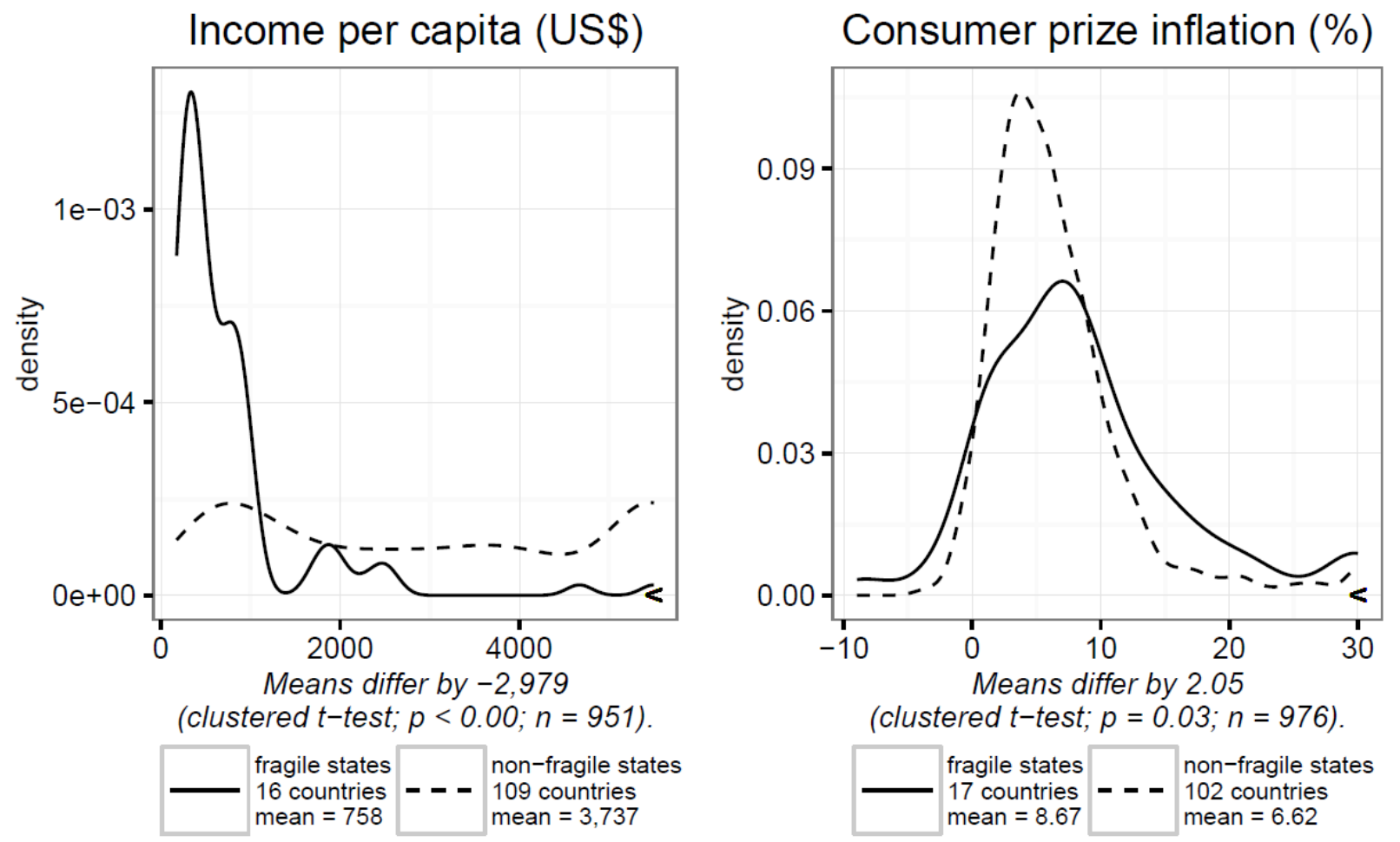

Figure 1: Income and Inflation

${ }^{17}$ If not otherwise noted, all data are taken from the World Development Indicators (World Bank 2016). 

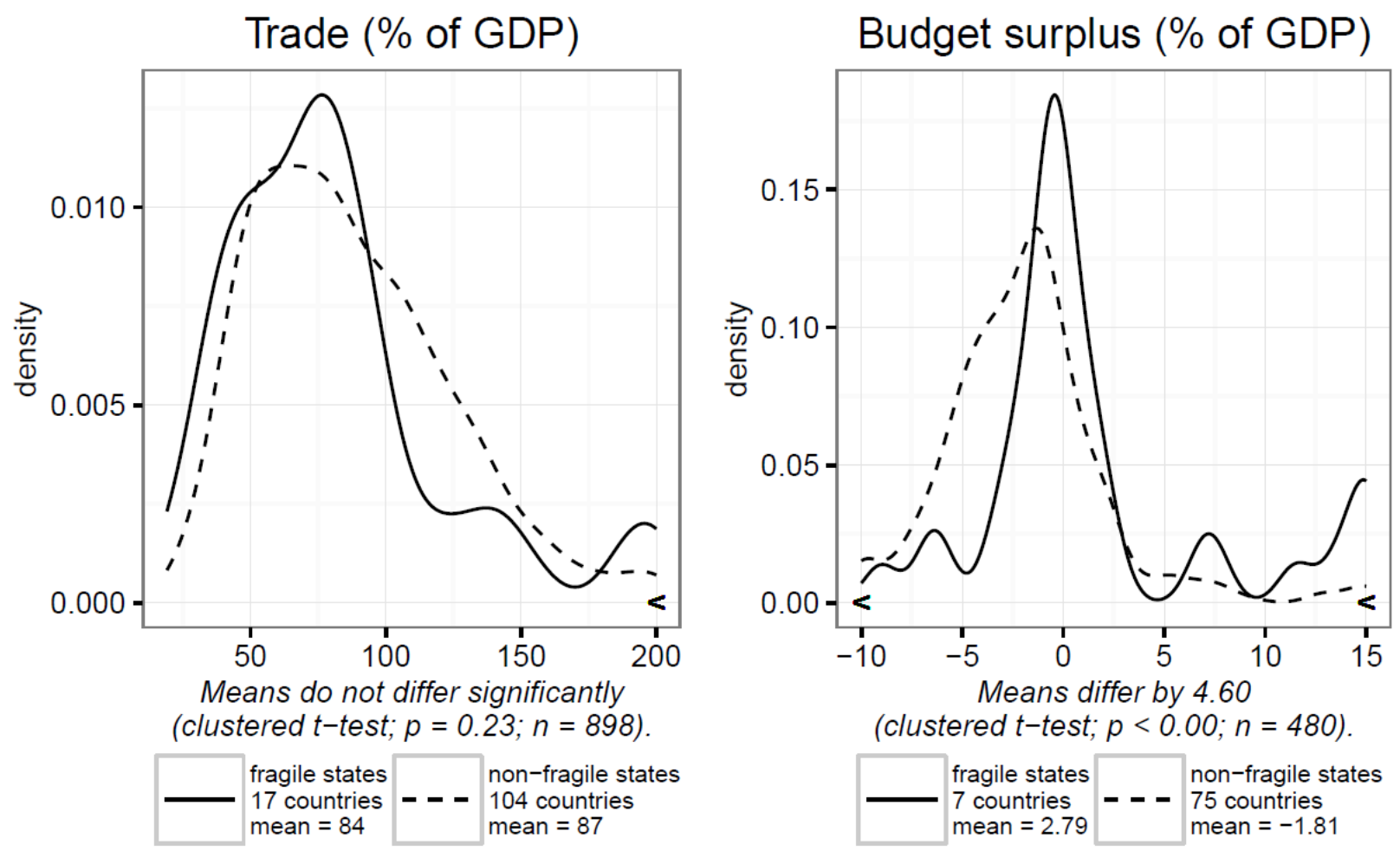

Figure 2: Trade and budget deficit

Turning to the variables related to Burnside and Dollar's (2000) "good policy"-model, inflation in fragile states is on average about two percentage points higher than in non-fragile states (right panel of figure 1). Trade constitutes about the same average share of gross domestic product (GDP) in fragile and non-fragile states (left panel of figure 2). Some fragile states have very high trade ratios of 200 percent and more. The third variable in Burnside and Dollar's model, budget deficit, is only available for 7 fragile states in our sample, so the comparison has limited value (right panel of figure 2). Those fragile states for which we observe budget balances are less likely to have deficits and more likely to have large surpluses than non-fragile states. 

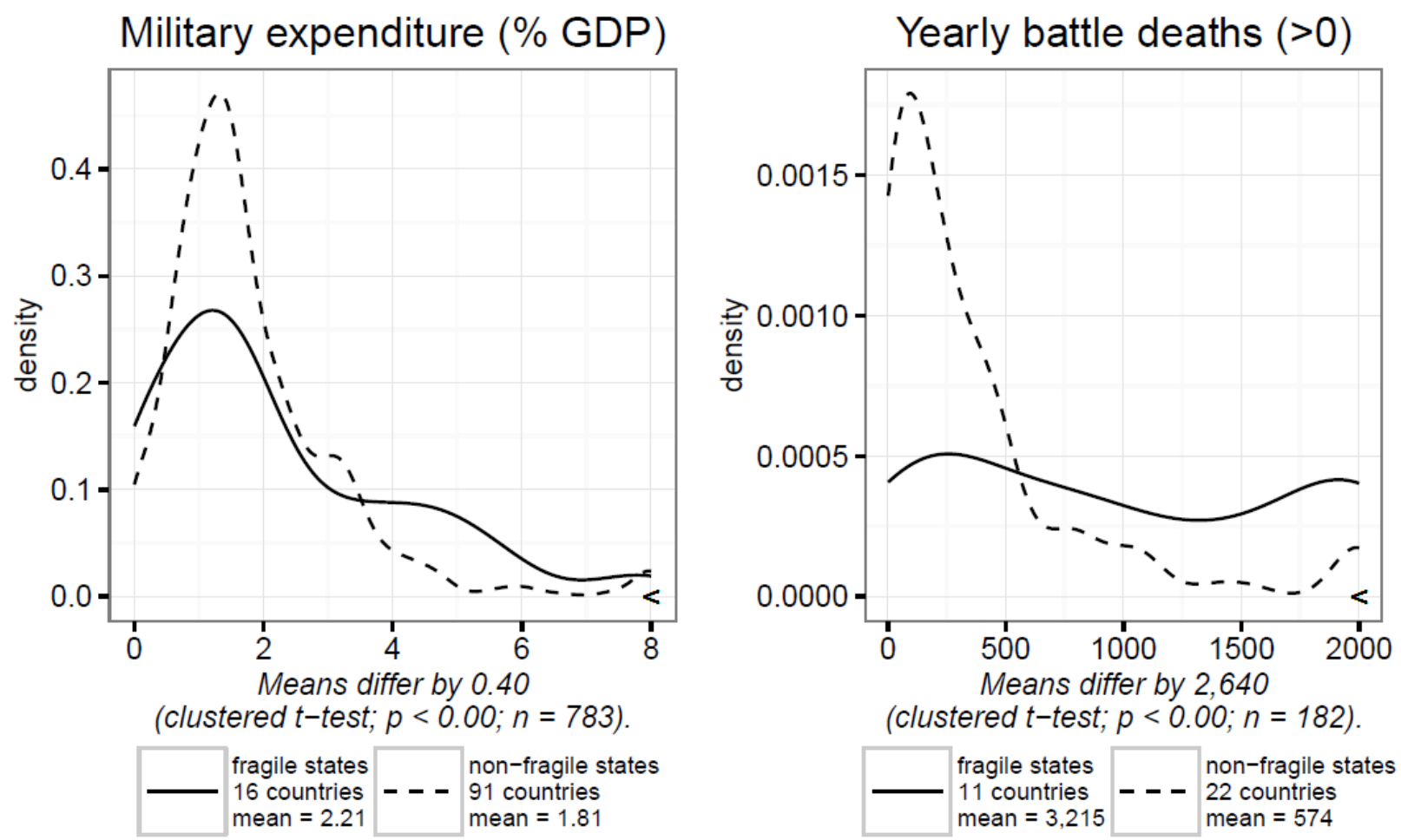

Figure 3: Military expenditure and battle deaths

Turning to the variables indicating political instability, fragile states employ their resources to spend slightly more on their militaries than non-fragile states (left panel of figure 3). When fragile states experience conflicts, they suffer considerably more battle deaths than nonfragile states: a conflict-year in the latter averages 542 deaths, a conflict-year in the former 3,048 deaths (right panel of figure 3; calculations based on Gleditsch et al. 2002). 

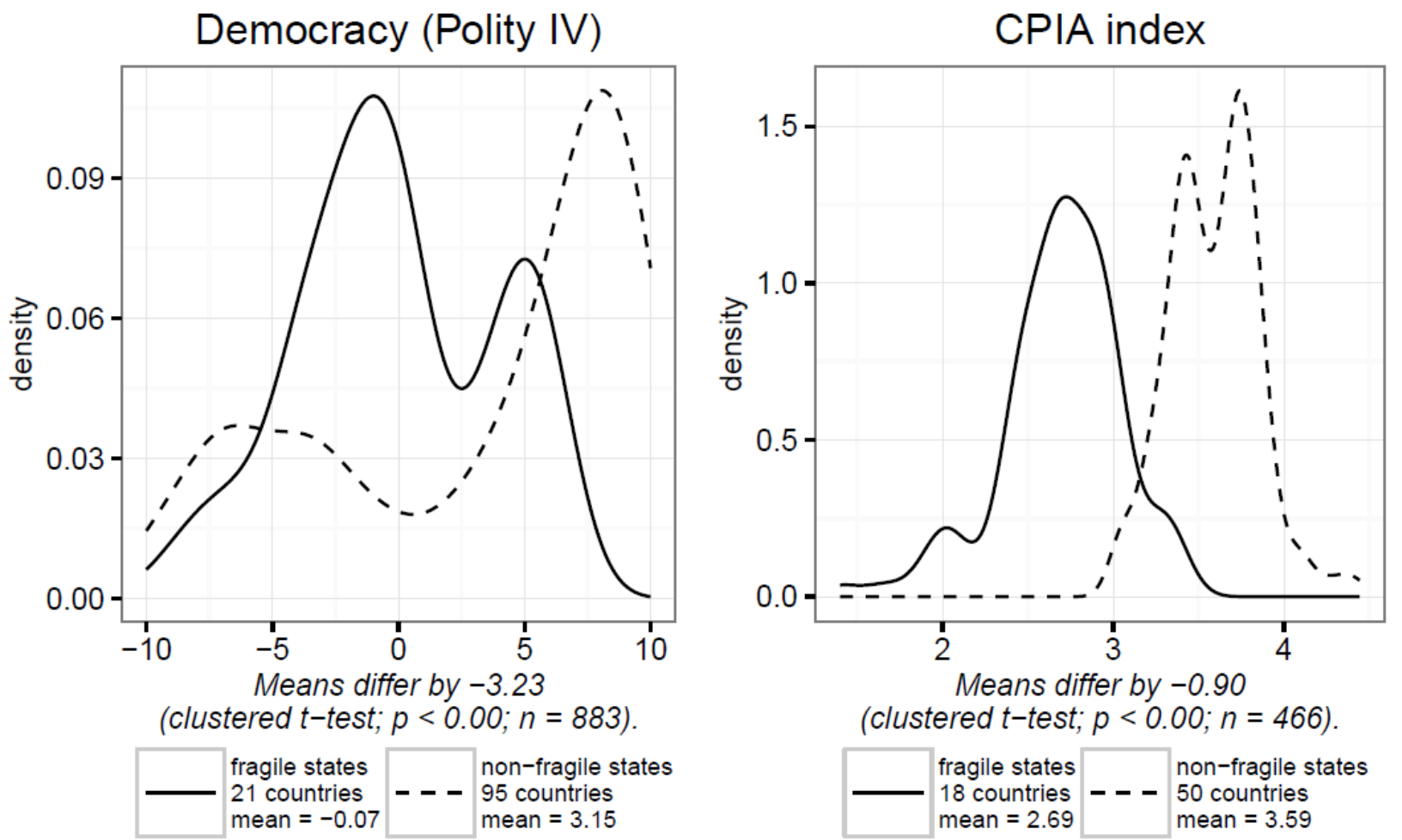

Figure 4: Democracy and institutional performance (CPIA)

Turning to the institutional setting, fragile states score 3 points less on the democracy index of the Polity IV project (left panel of figure 4; Marshall et al. 2011). What is even more salient is the predominance of "anocratic" systems in fragile states, i.e., countries that are neither perfect autocracies nor perfect democracies. Non-fragile states are closer to those stable poles of the spectrum. Fragile states also score much lower on the World Bank's CPIA index (right panel of figure 4). But since the CPIA is the main indicator driving the World Bank's fragile situations list, the almost perfect correlation that we observe is almost entirely by construction. 

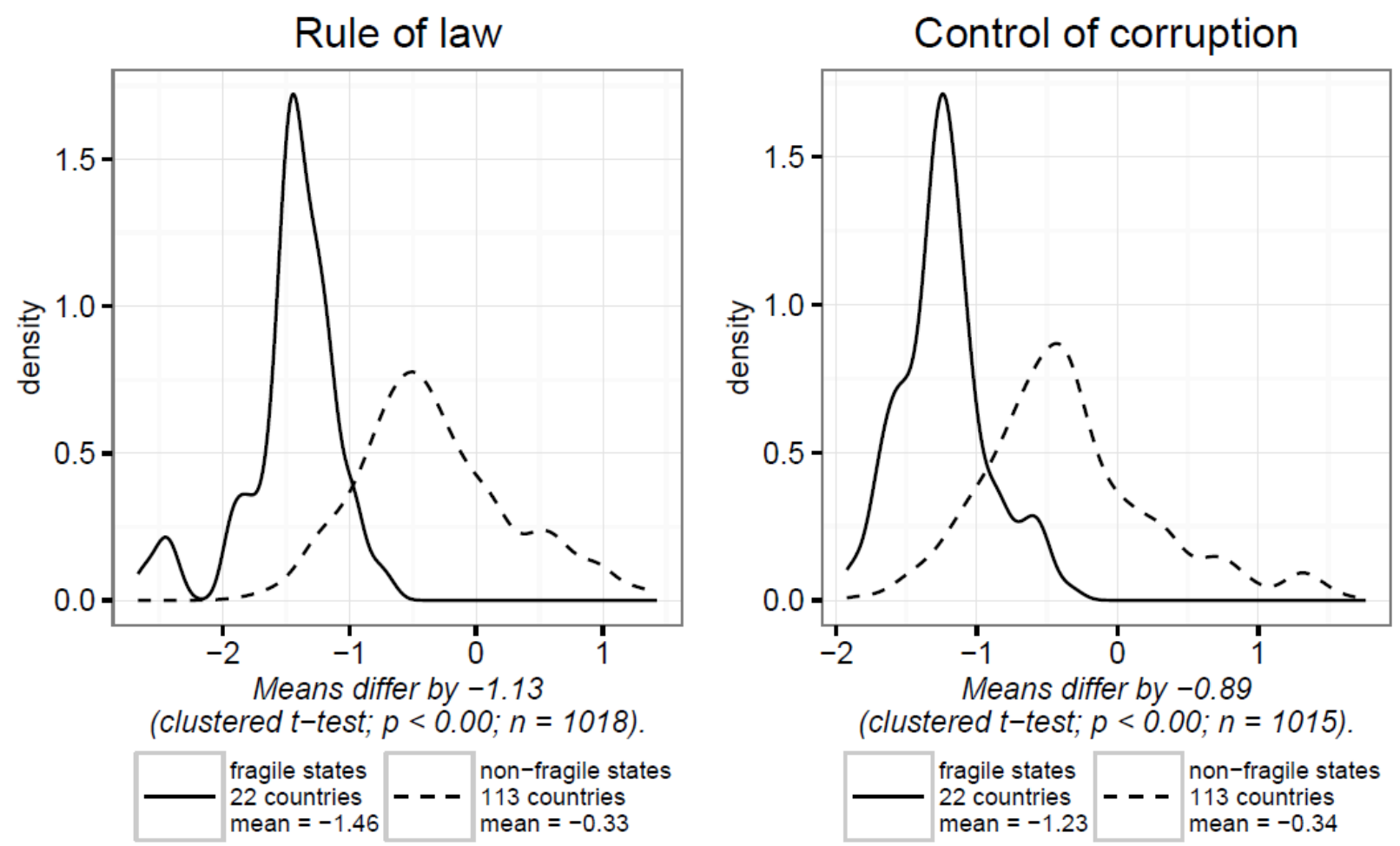

Figure 5: Rule of law and control of corruption

The Worldwide Governance Indicators (WGI; Kaufman and Kraay 2015) aim at providing a more detailed assessment of institutional quality, providing indicators on the rule of law and control of corruption, among others. On both, fragile states perform substantially worse compared to non-fragile states (figure 5). Note that zero constitutes the global average in the WGI indicators: none of the fragile states reach this benchmark.

In summary, fragile states are mostly very poor countries with slightly higher inflation rates and anocratic governments that perform badly in governance indicators. Fragile states spend more on the military and suffer substantially more battle deaths when in conflict. While being poor could make fragile states a prime target for poverty alleviation, a precarious security situation, bad governance, and weak institutions feature among the prime suspects that are detrimental to aid effectiveness. Proponents of the Burnside and Dollar (2000) "good policy"model would argue that the "policy distortions" in fragile states create disincentives to invest aid and thereby make it less effective in promoting economic growth compared to non-fragile states. 
Democracy - a potential driver of economic growth (Acemoglu et al. 2014) - is unlikely to be strengthened by aid flows, as it is not sufficiently developed in most fragile countries (Dutta et al. 2013). On the contrary, aid given to autocratic fragile states may increase the political survival of the countries' autocratic leaders and hinder democratic reforms (Bueno de Mesquita and Smith 2010). According to Svensson (1999) and Kosack (2003), aid will also be less effective for growth in non-democracies, including anocracies. A potential channel explaining the ineffectiveness is fungibility: In non-democracies, aid-receiving governments are less accountable to their citizens. This arguably enhances their opportunities to channel aid to sectors that most effectively promote development. While there is no scholarly consensus to what degree aid is indeed "fungible," many recent studies show that it is often not used for its original purpose. ${ }^{18}$ For instance, Collier and Hoeffler (2007) as well as Langlotz and Potrafke (2016) find that ODA, which excludes military usage by definition, increases military expenditure in recipient countries. Kono and Montinola (2012) find this effect to hold only in autocratic countries. In sum, we expect the lack of democracy in most fragile states to undermine aid effectiveness there.

In addition, a well-established literature has looked at the effects of aid in violent environments in more detail. Hirshleifer (1989) and Grossman (1992), for instance, argue that foreign aid may lead to conflicts by raising the value of capturing the state. Others hold that aid increases public goods provision and military capabilities of the state and thereby reduces the incentives to participate in violent activities against the state (Azam 1995; Fearon and Laitin 2003; Collier and Hoeffler 2004). In the recent empirical literature, Nunn and Qian (2014) provide evidence for the hypothesis that US food aid increases the probability of conflict as rebels can capture it and use it as a financing mechanism. In a similar vein, Bluhm et al. (2016) show that giving aid to countries with low-intensity conflicts increases the likelihood of an escalation of violence. The literature is thus skeptical towards the ability of aid to end violent conflicts in fragile states.

${ }^{18}$ However, according to Morrissey (2015: 98) "The extent to which aid is fungible is over-stated, and even where it is fungible this does not appear to make the aid less effective." See also Milner et al. (2016). 


\section{Donor characteristics and motives}

What characterizes the relationship between fragile states and foreign aid donors? Do fragile states receive aid from different types of donors compared to other recipients? Figure 6 (left panel) depicts whether fragile states tend to align politically with a major donor - the United States and whether they play a role in international decision-making. Developing countries in general rarely vote in-line with the United States in the United Nations General Assembly (UNGA): on average, their votes coincide in only 16 percent of decisions (calculations based on Bailey et al. 2017). Fragile states agree even less with the United States (on average 12 percent). And there are no fragile states among the countries that have a very high affinity with the United States.

Despite their uncertain internal conditions, fragile states are sometimes elected to the UN Security Council (right panel of figure 6; calculations based on Dreher et al. 2009a). Between 2006 and 2015, both the Republic of Congo and Chad served one term. ${ }^{19}$ But non-fragile states had a much higher likelihood of appearing several times on the council, serving on average half a year in the decade under observation, whereas fragile states, on average, served less than two months.

${ }^{19}$ Note that the Republic of Congo was a temporary member of the UN Security Council in 2006 and 2007 but according to our method is only classified as a fragile state in 2007. 

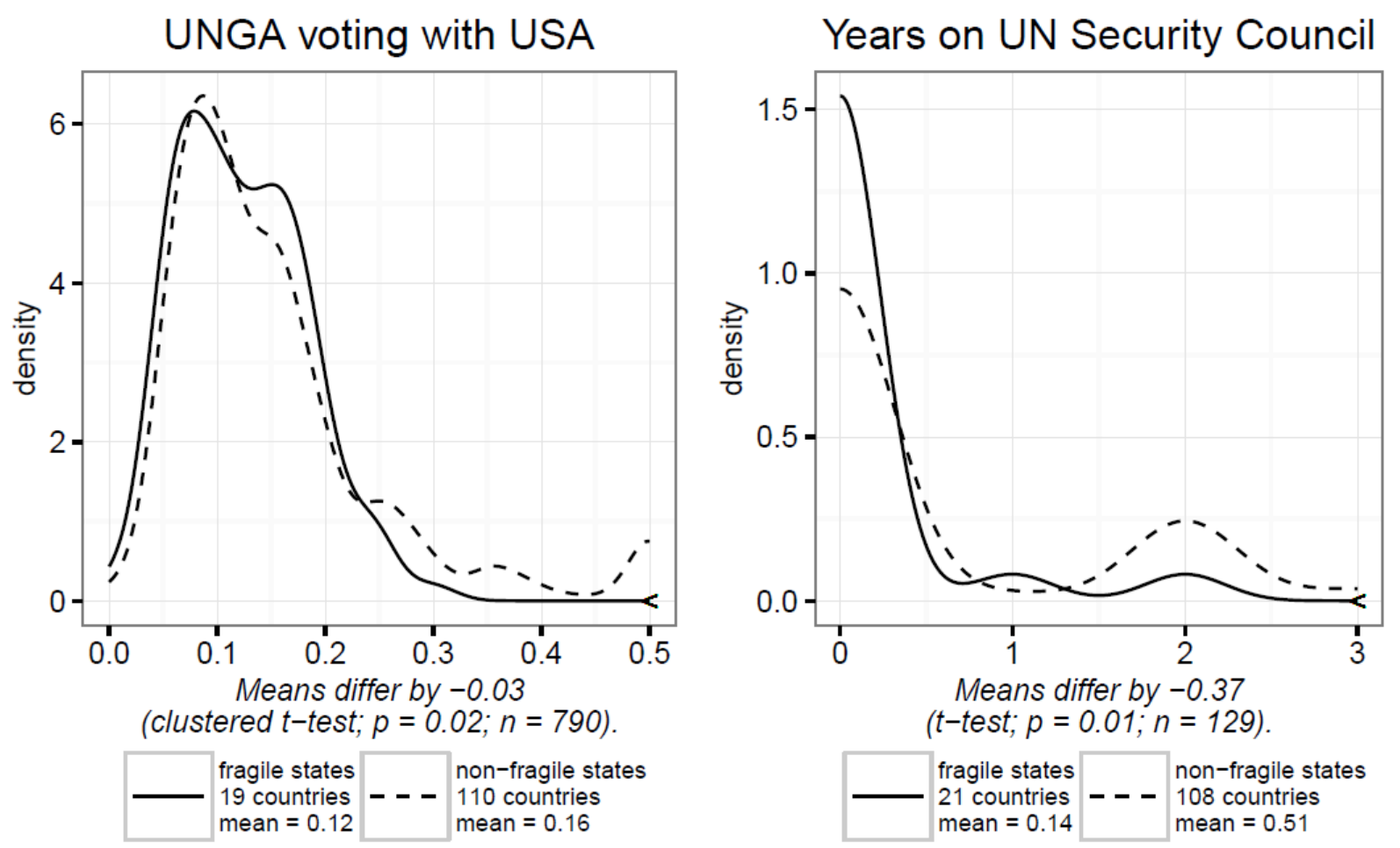

Figure 6: United Nations General Assembly voting and Security Council membership
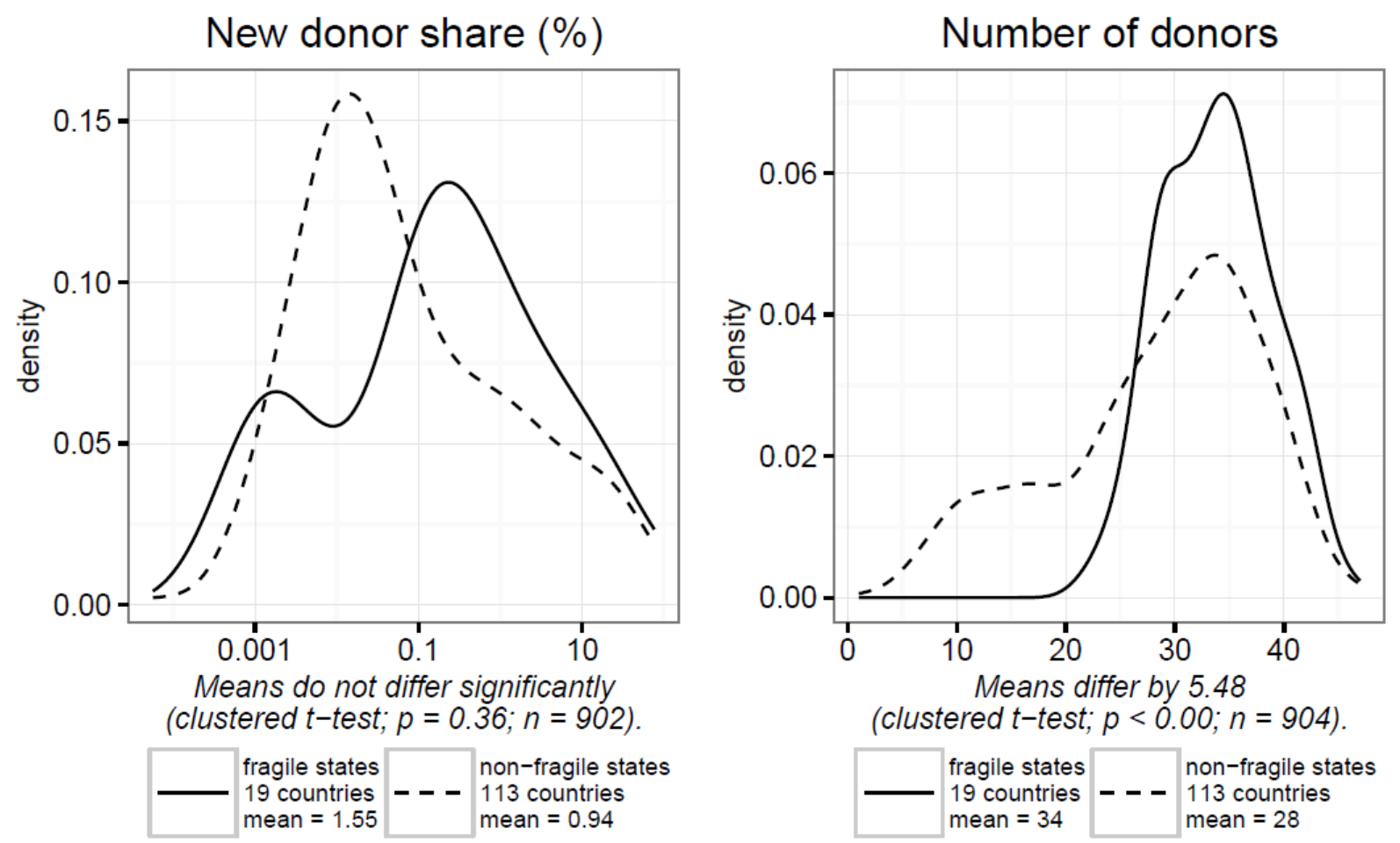

Figure 7: New donors and number of donors 
Are Western donors confronted with more competition in the aid business in fragile states? The data suggest they are not: The share of aid provided by new donors does not differ between fragile and non-fragile states (left panel of figure 7). ${ }^{20}$ One might expect new donors to be more interested in fragile states that export natural resources, but the lack of a statistically significant difference remains when considering only countries with a fuel export share over 50 percent. Still, Western donors might hinder themselves in fragile states. Fragile states attract, on average, five donors more than non-fragile states (right panel of figure 7). There is no fragile country with fewer than 20 donors present. This donor fragmentation may lead to inefficiencies and increased transaction costs in the delivery process. Knack and Rahman (2007) show that donor fragmentation bears particularly heavily on areas of limited statehood. Weak administrations have little means to hold strong against a plethora of donor requests and contain battles between donors (Faust et al. 2015).

Neither can citizens in fragile states hope to benefit from more effective multilateral aid. ${ }^{21}$ The data shows that only seven percent of the aid that fragile states receive comes from multilateral donors. This is not statistically different from the share in non-fragile states (left panel of figure 8). Northern donors ${ }^{22}$ however provide on average a higher share of aid in fragile states (ten versus six percent, see right panel of figure 8).

20 "New donors" are defined as non-OECD countries (Dreher et al. 2011). These and the following aid statistics have been calculated based on the AidData research release 3.0 (Tierney et al. 2011) unless otherwise noted. AidData is based on the OECD's Creditor Reporting System (CRS) but adds more detailed information on "traditional" and "new" donors.

${ }^{21}$ Multilateral aid is identified by the CRS bi-multi code 4 .

${ }^{22}$ Defined as Denmark, Finland, the Netherlands, Norway and Sweden by Minoiu and Reddy (2010). 

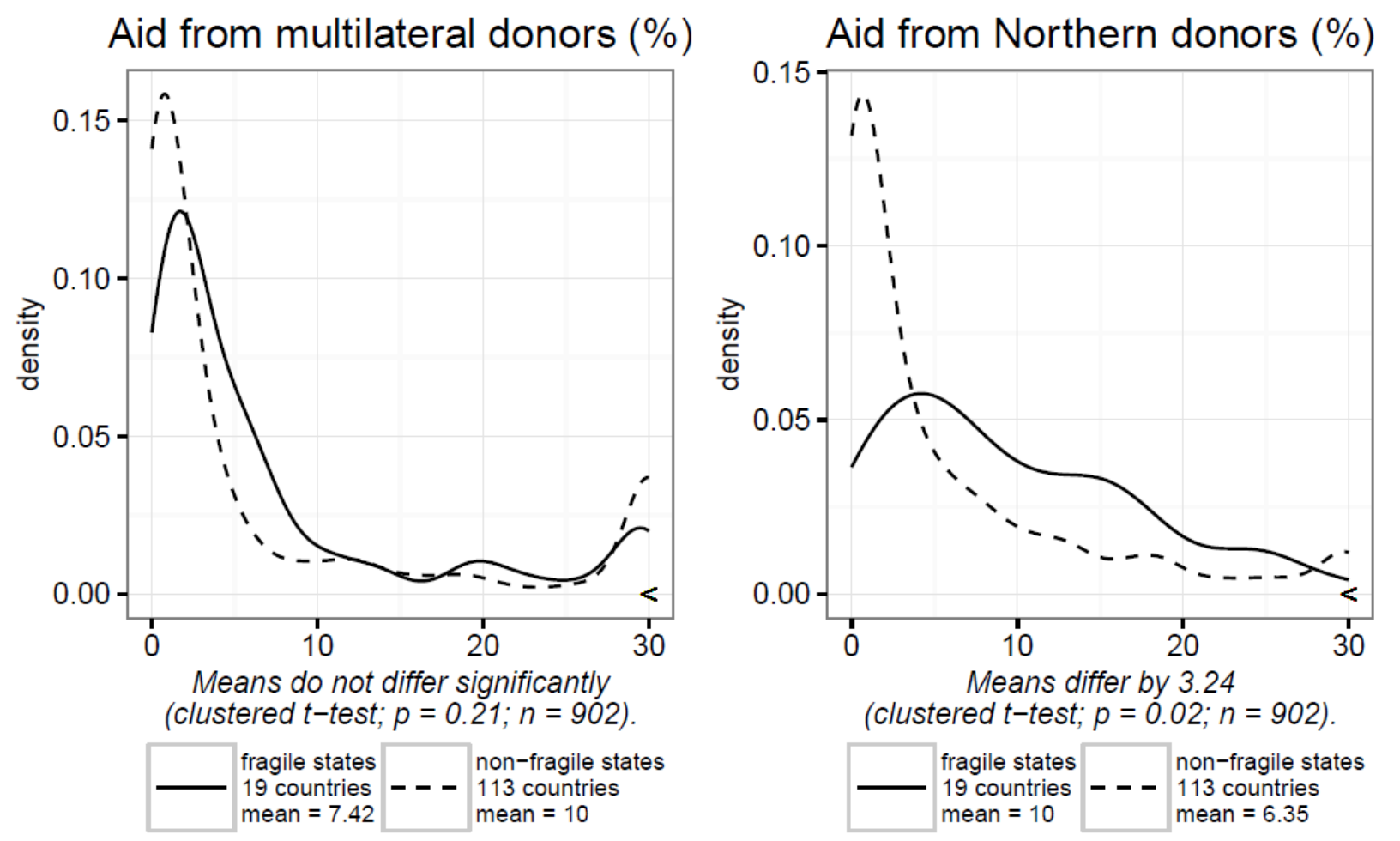

Figure 8: Multilateral and Northern donors

In summary, the donor characteristics in fragile states differ in some aspects from those of non-fragile states. In fragile states, the potentially harmful effects of more fragmentation could be partially balanced by the beneficial effects of more Northern donors and less pronounced geopolitical motivations for aid (as proxied by UN Security Council membership). This occurs despite the fact that fragile countries are poor, which arguably makes their votes in the UNSC and the UNGA cheaper to buy with aid. Due to the one-country-one-vote rule in these bodies, rich countries will ceteris paribus be more likely to target these countries to secure their votes (for a game theoretic model of vote buying in international organizations see Vreeland \& Dreher 2014).

One must consider, however, that the security situation in fragile states makes them geopolitically important for donor states eager to prevent the spread of instability. A large amount of aid is given to countries in which Western donor governments fight against terrorist groups, such as Iraq and Afghanistan (Fleck and Kilby 2010, Dreher and Fuchs 2011). Rather than being directly aimed at promoting social and economic development, in these settings, aid, more often 
than not, is intended to win or end violent conflicts (Goodhand and Sedra 2010). Given the recent empirical evidence on the negative effect of political motivation on aid's effectiveness, this is likely to reduce the effectiveness of development aid in fragile states.

Taken together, average donor characteristics provide little insight as to whether aid to fragile states is more or less effective. But because of their fragility these states are often important to certain donors and as such are more likely to receive politically motivated aid, which is generally less likely to be effective in promoting social and economic development.

\section{Aid characteristics}

Do the aid flows to fragile states have characteristics that allow a judgement on their expected effectiveness? In terms of aid's share of gross national income (GNI), fragile states outbid nonfragile states by a factor of three, with 15 versus 5 percent (left panel of figure 9; data from World Bank 2016). This is in part due to fragile states having lower GNIs. Aid commitments however also differ in absolute terms: fragile states receive on average half a billion USD more in aid commitments per year (right panel of figure 9). ${ }^{23}$

${ }^{23}$ We exclude debt relief, humanitarian aid and expenses in the donor country from our definition of foreign aid, as these types of aid are unlikely and not intended to induce economic growth. Including these marginal aid types makes the difference between fragile and non-fragile states vanish in terms of overall commitments, for example. 

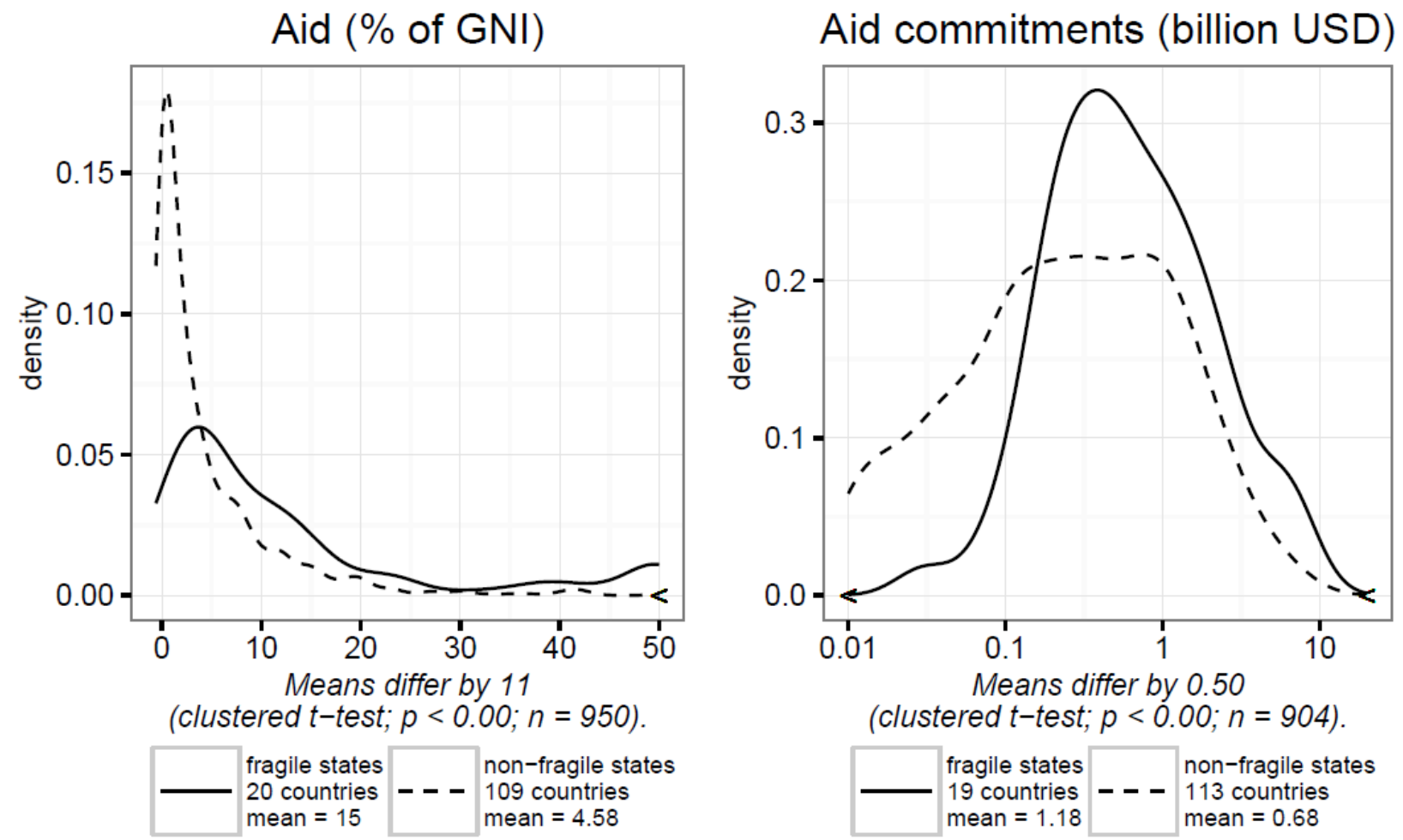

Figure 9: Aid amounts

Aid commitments per capita also differ, but conversely: fragile states receive 67 USD per capita on average, while non-fragile states receive 131 USD (left panel of figure 10). There is a large variance in both groups, however. The distribution ranges from a few dollars to hundreds of dollars per capita. In the group of fragile states, the lowest average aid-per-capita went to Eritrea, with 9 USD, the highest to Afghanistan, with 199 USD.

Since governments of fragile states are largely considered unreliable or illegitimate, it is surprising to see that some fragile states receive substantial amounts of budget aid (right panel of figure 10). What is more, average contributions of budget aid do not differ from non-fragile states. 

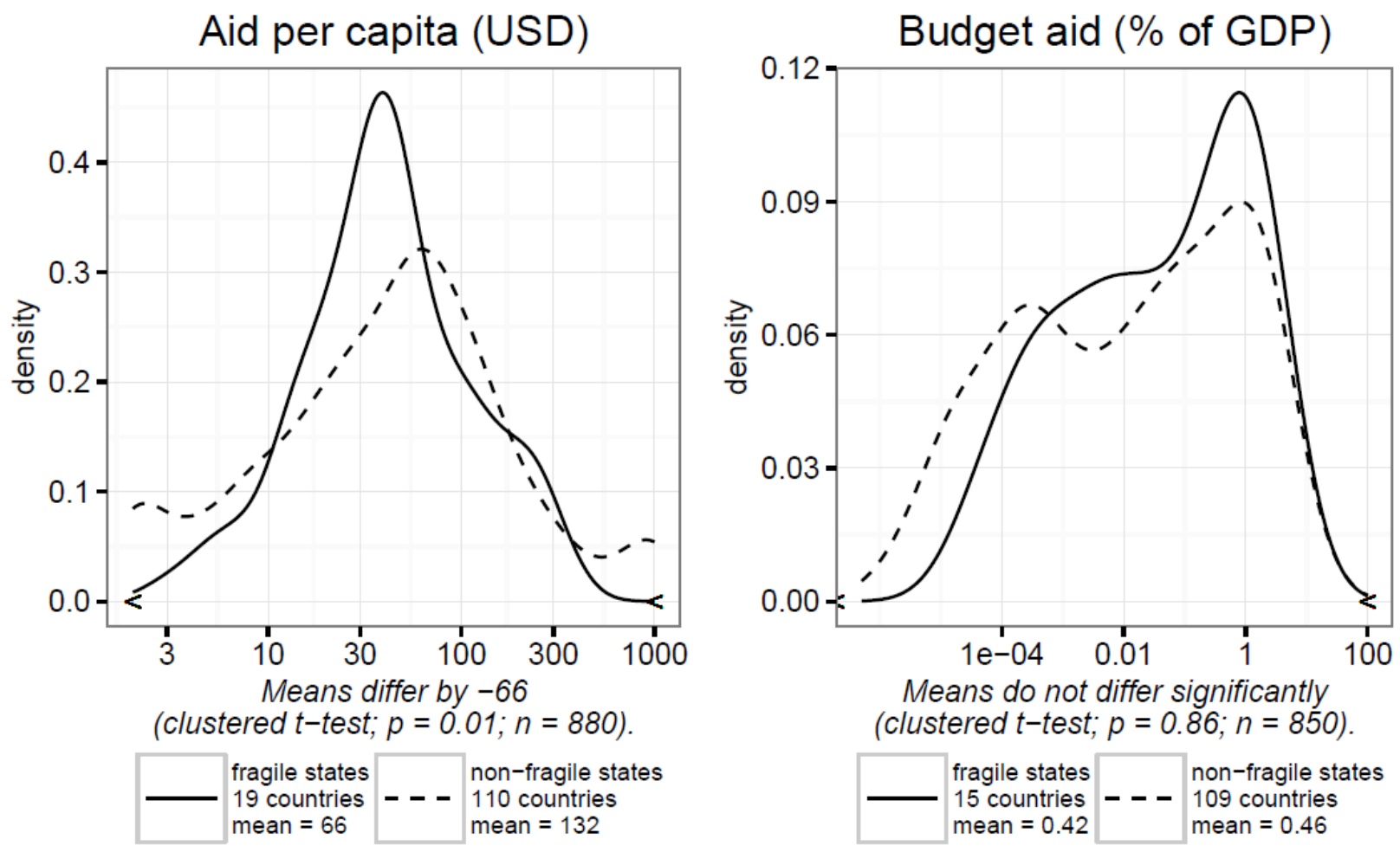

Figure 10: Aid per capita and budget aid

Contrary to budget aid, we find differences in the channels of delivery (figure 11). Less aid is channeled through governments in fragile states: they are involved in about one third less of the overall aid transactions than governments of non-fragile states (11 versus 18 percent). ${ }^{24}$ In particular, governments of fragile states are much more likely to handle less than 20 percent of the aid that flows into the country. This supports the idea that donors mistrust governments of fragile states. Donors often hesitate to cede full control over development projects to recipient governments as aid may help cement political structures that prevent developmental progress (Gisselquist 2015). Donors in fragile states do not, however, rely more strongly on nongovernmental organizations (NGOs). ${ }^{25}$ The shares of the aid budgets that are channeled through NGOs do not differ significantly from non-fragile states.

\footnotetext{
${ }^{24}$ CRS channel codes 12000 to 12999.

${ }^{25}$ CRS channel codes 23000 to 29999.
} 

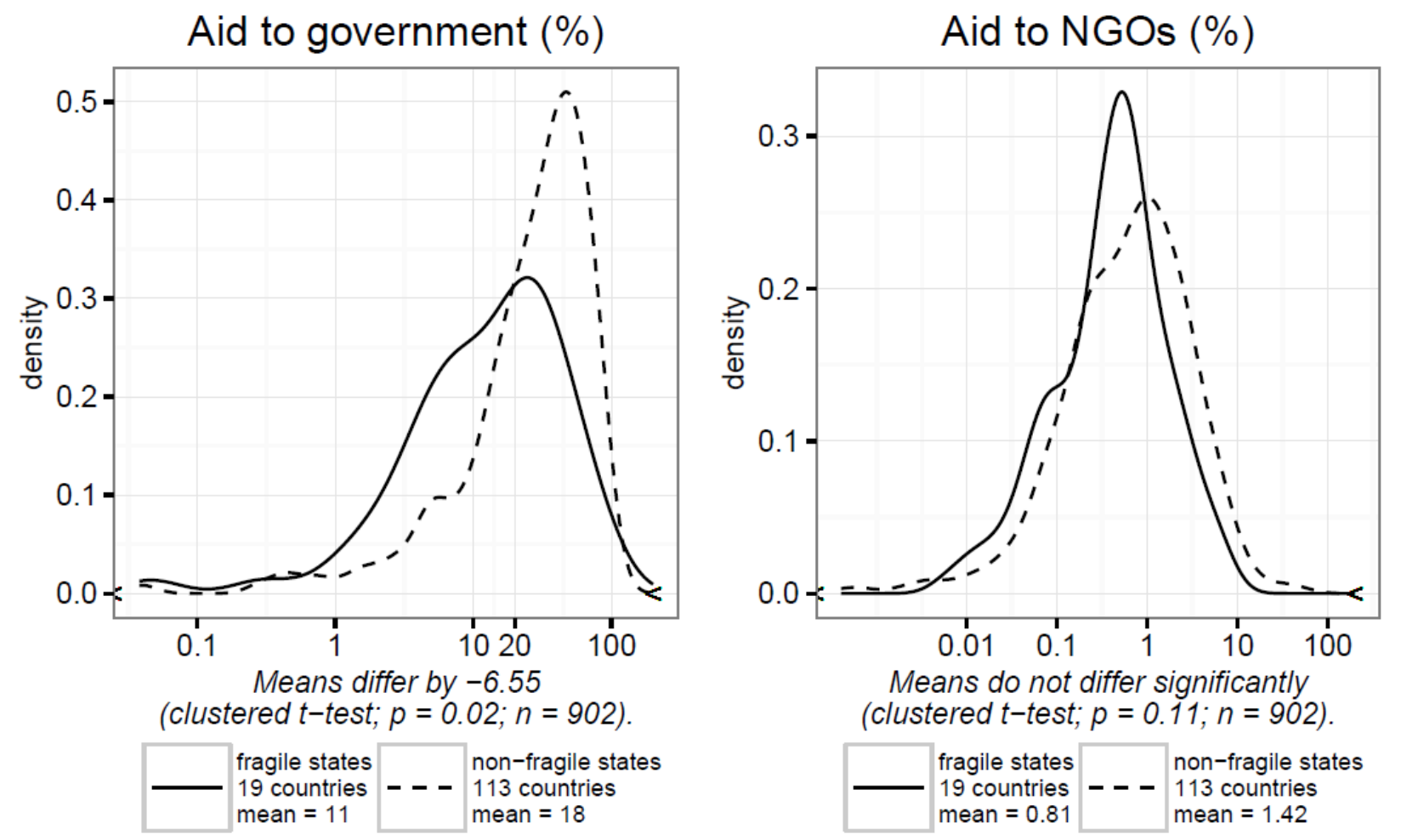

Figure 11: Aid channels

In summary, foreign aid commitments to fragile states are larger than to non-fragile states, both in absolute terms and as a share of GNI. At the same time, average aid per capita in fragile states is only half of that going to non-fragile states. If we apply the "medicine model" and expect decreasing returns of aid if it is given in abundance, we find that fragile states are more likely to receive "too much" aid. Following Clemens et al. (2012) in setting the "turning point" to an aid to GNI ratio of 15 percent, our data show that in several fragile states aid shares exceed this threshold.

When considering not only the amount but also the type of aid that is given, we find that in fragile states less aid goes directly to governments. The use of aid delivery channels other than the governments of fragile states may risk undermining domestic state-building efforts by creating parallel structures (Batley and Mcloughlin 2010). Such delivery tactics also run counter to the recommendations of the High Level Fora on Aid Effectiveness in Rome (2003), Paris (2005), Accra (2008) and Busan (2011), which support the "use of country systems" to avoid inefficiencies 
and to strengthen local institutions. Donors are likely to avoid these "country systems" because they mistrust the local political authorities - often for good reasons. Yet the channels they have to choose instead (e.g., project aid) are not the ones that make aid more effective for development.

The inconvenience of having a weak partner that is at risk of being overburdened while at the same time not being able to disburse per-capita amounts close to what non-fragile states receive is the core problem of aid effectiveness in fragile states. Both ways out of this impasse - a complete disengagement or externally led state-building - are politically difficult to sell in most donor countries.

\section{Conclusion}

The existing evidence on aid effectiveness does not allow drawing definitive conclusions concerning the expected effect of aid on social and economic development in areas of limited statehood. Nevertheless, the evidence we have at our disposal suggests that areas of limited statehood constitute a challenging environment for aid to be effective. The fact that the average fragile state has weak and undemocratic institutions, lacks "good policies," and does not receive the most effective types of aid makes us expect aid in areas of limited statehood, on average, to be less effective than elsewhere.

This does not, however, prompt the recommendation to discontinue giving aid to the group of fragile states. Rather, the evidence on conditional aid effectiveness suggests that the specifics matter. We do not find fragile states to constitute a homogenous group in terms of recipient, donor and aid characteristics. Their performance across indicators varies widely, as the spread of their distributions indicates. This is why we must differentiate with regards to the type of fragility that a state suffers from. Some states may be capable of benefitting from specific types of aid despite the bleak general picture. Carefully designed, well-targeted aid projects that also take into account the many factors that undermine aid effectiveness may still help to promote social and economic development in areas of limited statehood. And even if positive effects from aid on development in areas of limited statehood are often too much to ask for, aid can still alleviate humanitarian crises and disasters. Marginally improving the lives of the poorest in such 
situations is desirable even if developmental impacts that are visible on the macro-level are beyond the reach of aid. 


\section{References}

Acemoglu, Daron, Suresh Naidu, Pascual Restrepo and James Robinson, 2014, Democracy Does Cause Growth, NBER Working Paper No. 20004.

Acht, Martin, Toman Omar Mahmoud and Rainer Thiele, 2015, Corrupt Governments Do Not Receive More State-to-State Aid: Governance and the Delivery of Foreign Aid Through Non-State Actors, Journal of Development Economics 114: 20-33.

Ahmed, Faisal Z., 2012, The Perils of Unearned Foreign Income: Aid, Remittances, and Government Survival, American Political Science Review 106, 01: 146-165.

Anderson, Edward, 2012, Aid Fragmentation and Donor Transaction Costs, Economics Letters 117, 3: 799-802.

Askarov, Zohid and Hristos Doucouliagos, 2013, Does Aid Improve Democracy and Governance? Public Choice 157: 601-28.

Azam, Jean Paul, 1995, How to Pay for the Peace? A Theoretical Framework with References to African Countries, Public Choice 83, 1-2: 173-84.

Bailey, Michael A., Anton Strezhnev and Erik Voeten, 2017, Estimating Dynamic State Preferences from United Nations Voting Data, Journal of Conflict Resolution 61, 2: 430-456.

Baliamoune-Lutz, Mina and George Mavrotas, 2009, Aid Effectiveness: Looking at The AidSocial Capital-Growth Nexus, Review of Development Economics 13, 3: 510-525.

Batley, Richard and Claire Mcloughlin, 2010, Engagement with Non-State Service Providers in Fragile States: Reconciling State-Building and Service Delivery, Development Policy Review 28, 2: $131-54$.

Bazzi, Samuel and Michael A. Clemens, 2013, Blunt Instruments: Avoiding Common Pitfalls in Identifying the Causes of Economic Growth, American Economic Journal: Macroeconomics 5, 2: $152-86$.

Bermeo, Sarah Blodgett, 2011, Foreign Aid and Regime Change: A Role for Donor Intent, World Development 39, 11: 2021-2031.

Bertelsmann Transformation Index, 2016, Transformation Index BTI 2016: Political Management in International Comparison, Bertelsmann Stiftung. 
Bertho, Fabien, 2013, Presentation of the Institutional Profiles Database 2012 (Ipd 2012), Directorate General of the Treasury of the Ministry for the Economy and Finance and the Ministry of Foreign Trade (France). Accessed online at http://www.cepii.fr/institutions/doc/IPD_2012_cahiers-2013-03_EN.pdf.

Bigsten, Arne and Sven Tengstam, 2015, International Coordination and the Effectiveness of Aid, World Development 69: 75-85.

Birchler, Kassandra and Katharina Michaelowa, 2016, Making Aid Work for Education in Developing Countries: An Analysis of Aid Effectiveness for Primary Education Coverage and Quality, International Journal of Educational Development 48, May: 37-52.

Biscaye, Pierre, Katie P. Harris, Travis Reynolds and C. Leigh Anderson, 2015, Relative Effectiveness of Bilateral and Multilateral Aid on Development and Social Outcomes, Evans School of Policy Analysis and Research (EPAR) Brief No. 294.

Bjørnskov, Christian, 2013, Types of Foreign Aid, University of Aarhus Working Paper 2013-08.

Bluhm, Richard, Martin Gassebner, Sarah Langlotz and Paul Schaudt, 2016, Fueling conflict? (De)escalation and bilateral aid, CESifo Working Paper No. 6125.

Boone, Peter, 1996, Politics and the Effectiveness of Foreign Aid, European Economic Review 40, 2 : 289-329.

Briggs, Ryan C., 2014, Aiding and Abetting: Project Aid and Ethnic Politics in Kenya, World Development 64: 194-205.

Bueno de Mesquita, Bruce and Alastair Smith, 2010, Leader Survival, Revolutions, and the Nature of Government Finance, American Journal of Political Science 54, 4: 936-950.

Burnside, Craig and David Dollar, 2000, Aid, Policies and Growth, American Economic Review 90, 4: 847-868.

Cashel-Cordo, Peter and Steven G. Craig, 1990, The Public Sector Impact of International Resource Transfers, Journal of Development Economics 32, 1: 17-42.

Chauvet, Lisa and Patrick Guillaumont, 2003, Aid and Growth Revisited: Policy, Economic Vulnerability and Political Instability. CERDI Etudes et Documents E 2003.27.

Christensen, Zachary, Dustin Homer and Daniel L. Nielson, 2011, Dodging Adverse Selection: 
How Donor Type and Governance Condition Aid's Effects on School Enrollment, World Development 39, 11: 2044-2053.

Clemens, Michael A., Steven Radelet, Rikhil R. Bhavnani and Samuel Bazzi, 2012, Counting Chickens When They Hatch: Timing and the Effects of Aid on Growth, Economic Journal 122: 590-617.

Collier, Paul and David Dollar, 2002, Aid Allocation and Poverty Reduction, European Economic Review 46, 8: 1475-1500.

Collier, Paul and Anke Hoeffler, 2004, Greed and Grievance in Civil War, Oxford Economic Papers 56, 4: 563-95.

Collier, Paul and Anke Hoeffler, 2007, Unintended Consequences: Does Aid Promote Arms Races? Oxford Bulletin of Economics and Statistics 69, 1: 1-27.

Dalgaard, Carl-Johan, Henrik Hansen and Finn Tarp, 2004, On the Empirics of Foreign Aid and Growth, The Economic Journal 114, 496: F191-F216.

Dietrich, Simone, 2013, Bypass or Engage? Explaining Donor Delivery Tactics in Foreign Aid Allocation, International Studies Quarterly 57, 4: 698-712.

Djankov, Simeon, Jose Garcia-Montalvo and Marta Reynal-Querol, 2006, Does Foreign Aid Help? Cato Journal 26, 1: 1-28.

Djankov, Simeon, Jose Garcia-Montalvo and Marta Reynal-Querol, 2008, The Curse of Aid, Journal of Economic Growth 13, 3: 169-194.

Djankov, Simeon, Jose G. Montalvo and Marta Reynal-Querol, 2009, Aid with Multiple Personalities, Journal of Comparative Economics 37, 2: 217-229.

Donaubauer, Julian and Peter Nunnenkamp, 2016, Is Aid for Infrastructure Effective? A Difference-In-Difference-In-Differences Approach, Economics Bulletin 36, 2: 857-870.

Donaubauer, Julian, Birgit Meyer and Peter Nunnenkamp, 2016, Aid, Infrastructure, and FDI: Assessing the Transmission Channel with a New Index of Infrastructure, World Development 78: 230-245.

Doucouliagos, Hristos, 2016, The Politics of International Aid, In: R. Congleton, B. Grofman, S. Voigt (Eds.), Oxford Handbook of Public Choice, forthcoming. 
Doucouliagos, Hristos and Martin Paldam, 2009, The Aid Effectiveness Literature: The Sad Results of 40 Years of Research, Journal of Economic Surveys 23, 3: 433-461.

Dreher, Axel and Andreas Fuchs, 2011, Does Terror Increase Aid? Public Choice 149: 337-363.

Dreher, Axel and Kai Gehring, 2012, Does Aid Buy (Economic) Freedom? In: James Gwartney, Robert Lawson and Joshua Hall (Eds.), Economic Freedom of the World: 2012 Annual Report, Fraser Institute: 219-246.

Dreher, Axel, Stephan Klasen, James Raymond Vreeland and Eric Werker, 2013, The Costs of Favoritism: Is Politically-Driven Aid Less Effective? Economic Development and Cultural Change 62: 157-191.

Dreher, Axel and Sarah Langlotz, 2015, Aid and Growth. New Evidence Using an Excludable Instrument, CEPR Discussion Paper No. 10811.

Dreher, Axel and Steffen Lohmann, 2015, Aid and Growth at the Regional Level, Oxford Review of Economic Policy 31: 420-446.

Dreher, Axel, Sarah Langlotz and Silvia Marchesi, 2017, Information Transmission and Ownership Consolidation in Aid Programs, Economic Inquiry, forthcoming.

Dreher, Axel, Anna Minasyan and Peter Nunnenkamp, 2015, Government Ideology in Donor and Recipient Countries: Does Political Proximity Matter for the Effectiveness of Aid? European Economic Review 79: 80-92.

Dreher, Axel, Jan-Egbert Sturm and James Raymond Vreeland, 2009a, Development Aid and International Politics: Does Membership on The UN Security Council Influence World Bank Decisions? Journal of Development Economics 88, 1: 1-18.

Dreher, Axel, Jan-Egbert Sturm and James Raymond Vreeland, 2009b, Global Horse Trading: IMF Loans for Votes in the United Nations Security Council, European Economic Review 53: 742757.

Dreher, Axel, Peter Nunnenkamp and Rainer Thiele, 2008a, Does Aid for Education Educate Children? Evidence from Panel Data, World Bank Economic Review 22, 2: 291-314.

Dreher, Axel, Peter Nunnenkamp and Rainer Thiele, 2008b, Does US Aid Buy UN General Assembly Votes? A Disaggregated Analysis, Public Choice 136, 1: 139-164. 
Dreher, Axel, Peter Nunnenkamp and Rainer Thiele, 2011, Are 'New' Donors Different? Comparing the Allocation of Bilateral Aid Between Non-DAC and DAC Donor Countries, World Development 39, 11: 1950-1968.

Dreher, Axel, Peter Nunnenkamp, Susann Thiel and Rainer Thiele, 2012a, Aid Allocation by German NGOs: Does the Degree of Public Refinancing Matter? World Economy 35, 11: 1448-1472.

Dreher, Axel, Peter Nunnenkamp, Hannes Öhler and Johannes Weisser, 2012b, Financial Dependence and Aid Allocation by Swiss NGOs: A Panel Tobit Analysis, Economic Development and Cultural Change 60, 4: 829-867.

Dreher, Axel, Vera Eichenauer and Kai Gehring, 2016, Geopolitics, Aid and Growth: The Impact of UN Security Council Membership on the Effectiveness of Aid, World Bank Economic Review, forthcoming.

Dutta, Nabamita, Peter T. Leeson and Claudia R. Williamson, 2013, The Amplification Effect: Foreign Aid's Impact on Political Institutions, Kyklos 66, 2: 208-28.

Easterly, William, Ross Levine and David Roodman, 2004, Aid, Policies, and Growth: Comment, American Economic Review 94, 3: 774-780.

Edwards, Michael and David Hulme, 1996, Too Close for Comfort? The Impact of Official Aid on Nongovernmental Organizations, World Development 24, 6: 961-973.

Faust, Jörg, Jörn Grävingholt and Sebastian Ziaja, 2015, Foreign Aid and the Fragile Consensus on State Fragility, Journal of International Relations and Development 18, 4: 407-27.

Fearon, James D. and David D. Laitin, 2003, Ethnicity, Insurgency, and Civil War, American Political Science Review 97, 1: 75.

Feeny, Simon and Mark McGillivray, 2011, Scaling-up Foreign Aid: Will the 'Big Push' Work? World Economy 34, 1: 54-73.

Feeny, Simon and Ashton de Silva, 2013, Measuring Absorptive Capacity Constraints to Foreign Aid, Economic Modelling 29, 3: 725-733. 
Findley, Michael G., Helen V. Milner and Daniel L. Nielson, 2016, The Choice Among Aid Donors: The Effects of Multilateral vs. Bilateral Aid on Recipient Behavioral Support, Review of International Organizations, forthcoming.

Fleck, Robert K. and Christopher Kilby, 2010, Changing Aid Regimes? U.S. Foreign Aid from the Cold War to The War on Terror, Journal of Development Economics 91, 2: 185-197.

Galiani, Sebastian, Stephen Knack, Lixin C. Xu and Ben Zou, 2016, The Effect of Aid on Growth: Evidence from a Quasi-Experiment, Journal of Economic Growth, forthcoming.

Gehring, Kai, Katharina Michaelowa, Axel Dreher and Franziska Spörri, 2015, Do We Know What We Think We Know? Aid Fragmentation and Effectiveness Revisited, Courant Research Centre: Poverty, Equity and Growth - Discussion Paper No. 185.

Girod, Desha, 2008, Cut from the Same Cloth? Multilateral vs. Bilateral Aid, Annual Meeting of the International Political Economy Society, Philadelphia.

Girod, Desha, 2012, Effective Foreign Aid Following Civil War: The Nonstrategic-Desperation Hypothesis, American Journal of Political Science 56, 1: 188-201.

Gisselquist, Rachel M, 2015, Varieties of Fragility: Implications for Aid, Third World Quarterly 36, 7: $1269-80$.

Gleditsch, Nils Petter, Peter Wallensteen, Mikael Eriksson, Margareta Sollenberg and Håvard Strand, 2002, Armed Conflict 1946-2001: A New Dataset, Journal of Peace Research 39, 5: 615-37.

Goodhand, Jonathan and Mark Sedra, 2010, Who Owns the Peace? Aid, Reconstruction, and Peacebuilding in Afghanistan, Disasters 34, 1: 78-102.

Grävingholt, Jörn, Sebastian Ziaja and Merle Kreibaum, 2015, Disaggregating State Fragility: A Method to Establish a Multidimensional Empirical Typology, Third World Quarterly 36, 7: 1281-98.

Grossman, Herschell, 1992, Foreign Aid and Insurrection, Defence Economics 3: 275-88.

Hadjimichael, Michael T., Dhaneshwar Ghura, Martin Mühleisen, Roger Nord and E. Murat Ucer, 1995, Sub-Saharan Africa: Growth, Savings, and Investment, 1986-93, IMF Occasional Paper No. 118. 
Headey, Derek, 2008, Geopolitics and the Effect of Foreign Aid on Economic Growth: 1970-2001, Journal of International Development 20, 161-180.

Hirshleifer, Jack, 1989, Conflict and Rent-Seeking Success Functions: Ratio vs. Difference Models of Relative Success, Public Choice 63, 2: 101-12.

Ioannidis, John P. A., Tom D. Stanley and Hristos Doucouliagos, 2016, The Power of Bias in Economics Research, Economic Journal, forthcoming.

Jelovac, Izabela and Frieda Vandeninden, 2008, How Should Donors Give Foreign Aid? Project Aid versus Budget Support, CREPP Working paper No. 13.

Jensen, Peter Sandholt and Martin Paldam, 2006, Can the Two New Aid-Growth Models be Replicated? Public Choice 127, 1-2: 147-175.

Jerven, Morten, 2013, Comparability of GDP Estimates in Sub-Saharan Africa: The Effect of Revisions in Sources and Methods Since Structural Adjustment, Review of Income and Wealth 59, S1: S16-S36.

Kaufman, Daniel and Aart Kraay, 2015, The Worldwide Governance Indicators. http://info.worldbank.org/governance/wgi/.

Kersting, Erasmus and Christopher Kilby, 2014, Aid and Democracy Redux, European Economic Review 67: 125-143.

Kilby, Christopher and Axel Dreher, 2010, The Impact of Aid on Growth Revisited: Do Donor and Recipient Characteristics Make a Difference? Economics Letters 107, 3: 338-340.

Kilby, Christopher, 2013, The Political Economy of Project Preparation: An Empirical Analysis of World Bank Projects, Journal of Development Economics 105: 211-225.

Kilby, Christopher, 2015, Assessing the Impact of World Bank Preparation on Project Outcomes, Journal of Development Economics 115: 111-23.

Kimura, Hidemi, Yuko Mori and Yasuyuki Sawada, 2012, Aid Proliferation and Economic Growth: A Cross-Country Analysis, World Development 40, 1: 1-10.

Knack, Stephen and Aminur Rahman, 2007, Donor Fragmentation and Bureaucratic Quality in Aid Recipients, Journal of Development Economics 83, 1: 176-97. 
Koch, Dirk J., Axel Dreher, Peter Nunnenkamp and Rainer Thiele, 2009, Keeping a Low Profile: What Determines the Allocation of Aid by Non-Governmental Organizations? World Development 37, 5: 902-918.

Koeberle, Stefan, Zoran Stavreski and Jan Walliser (Eds.), 2006, Budget Support as More Effective Aid? Recent Experiences and Emerging Lessons, World Bank Publications.

Kono, Daniel Yuichi and Gabriella R. Montinola, 2009, Does Foreign Aid Support Autocrats, Democrats, or Both? The Journal of Politics 71, 02: 704-718.

Kono, Daniel Yuichi and Gabriella R. Montinola, 2012, The Uses and Abuses of Foreign Aid: Development Aid and Military Spending, Political Research Quarterly 66, 3: 615-29.

Kosack, Stephen, 2003, Effective Aid: How Democracy Allows Development Aid to Improve the Quality of Life, World Development 31, 1: 1-22.

Kuziemko, Ilyana and Eric Werker, 2006, How Much is a Seat on the Security Council Worth? Foreign Aid and Bribery at the United Nations, Journal of Political Economy 114, 5: 905-930. Langlotz, Sarah and Niklas Potrafke, 2016, Does Development Aid Increase Military Expenditure? CESifo Working Paper No. 6088, 2016.

Lee, Melissa M., Gregor Walter-Drop and John Wiesel, 2014, Taking the State (Back) Out? Statehood and the Delivery of Collective Goods, Governance 27, 4: 635-54.

Marshall, Monty G., Keith Jaggers and Ted Robert Gurr, 2011, Polity IV Project: Political Regime Characteristics and Transitions, 1800-2011, Center for Systemic Peace.

Marshall, Monty G., Ted Robert Gurr and Barbara Harff, 2016, PITF - State Failure Problem Set: Internal Wars and Failures of Governance, 1955, Political Instability Task Force (PITF). http://www.systemicpeace.org/inscr/PITFProbSetCodebook2015.pdf.

Milner, Helen V., 2006, Why Multilateralism? Foreign Aid and Domestic Principal-Agent Problems, In: Darren G. Hawkins, David A. Lake, et al. (Eds.), Delegation and Agency in International Organizations, New York, Cambridge University Press :107-139.

Milner, Helen V. and Dustin Tingley, 2013, The Choice for Multilateralism: Foreign Aid and American Foreign Policy, Review of International Organizations 8, 3: 313-341.

Milner, Helen V., Daniel L. Nielson and Michael G. Findley, 2016, Citizen Preferences and Public 
Goods: Comparing Preferences for Foreign Aid and Government Programs in Uganda, Review of International Organizations 11, 2: 219-245.

Minasyan, Anna, 2016, Your Development or Mine? Effects of Donor-Recipient Cultural Differences on the Aid-Growth Nexus, Journal of Comparative Economics 44, 2: 309-325.

Minasyan, Anna, Peter Nunnenkamp and Katharina Richert, 2016, Does Aid Effectiveness Depend on the Quality of Donors? Working Paper 2046, Kiel Institute for the World Economy.

Minoiu, Camelia and Sanjay G. Reddy, 2010, Development Aid and Economic Growth, Quarterly Review of Economics and Finance 50, 1: 27-39.

Morrissey, Oliver, 2015, Aid and government fiscal behavior: Assessing recent evidence, World Development 69: 98-105.

Nunn, Nathan and Nancy Qian, 2014, U.S. Food Aid and Civil Conflict, American Economic Review 104, 6: 1630-66.

Nunnenkamp, Peter and Hannes Öhler, 2011, Throwing Foreign Aid at HIV/AIDS in Developing Countries: Missing the Target? World Development 39, 10: 1704-23.

Presbitero, Andrea F., 2016, Too Much and Too Fast? Public Investment Scaling-up and Absorptive Capacity, Journal of Development Economics 120, 17-31.

Radelet, Steven, 2004, Aid Effectiveness and the Millennium Development Goals. Center for Global Development Working Paper 39.

Rajan, Raghuram G. and Arvind Subramanian, 2007, Does Aid Affect Governance? American Economic Review 97, 2: 322-327.

Rajan, Raghuram G. and Arvind Subramanian, 2008, Aid and Growth, Review of Economics and Statistics 90, 4: 643-665.

Riddell, Roger C., Anthony Bebbington and Lennart Peck, 1995, Promoting Development by Proxy: An Evaluation of the Development Impact of Government Support to Swedish NGOs, Stockholm: SIDA. 
Risse, Thomas, 2011, Governance in Areas of Limited Statehood. In: Thomas Risse (Ed.): Governance without a State? Policies and Politics in Areas of Limited Statehood, Columbia University Press: 1-36.

Roodman, David, 2012, An Index of Donor Performance, Center for Global Development Working Paper No. 67, Washington, D.C.

Selaya, Pablo and Rainer Thiele, 2012, The Impact of Aid on Bureaucratic Quality: Does the Mode of Delivery Matter? Journal of International Development 24, 3: 379-386.

Svensson, Jakob, 1999, Aid, Growth and Democracy, Economics E Politics 11, 3: 275-297.

Tendler, Judith, 1982, Turning Private Voluntary Organizations into Development Agencies. Questions for Evaluation, AID Program Evaluation Discussion Paper 12, Washington, D.C. Tierney, Michael J., Daniel L. Nielson, Darren G. Hawkins, J. Timmons Roberts, Michael G. Findley, Ryan M. Powers, Bradley Parks, Sven E. Wilson and Robert L. Hicks, 2011, More Dollars Than Sense: Refining Our Knowledge of Development Finance Using AidData, World Development 39, 11: 1891-1906.

Vreeland, James Raymond and Axel Dreher, 2014, The Political Economy of the United Nations Security Council, Cambridge, Cambridge University Press.

Werker, Eric D., 2012, The Political Economy of Bilateral Foreign Aid, In: Gerard Caprio (Ed.): Handbook of Safeguarding Global Financial Stability: Political, Social, Cultural, and Economic Theories and Models, U.K., Academic Press: 47-58.

Werker, Eric D., Faisal Z. Ahmed and Charles Cohen, 2009, How is Foreign Aid Spent? Evidence from a Natural Experiment, American Economic Journal: Macroeconomics 1, 2: 225-244.

Williamson, Claudia R., 2008, Foreign Aid and Human Development: The Impact of Foreign Aid to the Health Sector, Southern Economic Journal 75, 1: 188-207.

World Bank, 2016, World Development Indicators, http://data.worldbank.org/datacatalog/world-development-indicators.

Yontcheva, Boriana and Nadia Masud, 2005, Does Foreign Aid Reduce Poverty? Empirical Evidence from Nongovernmental and Bilateral Aid. IMF Working Papers No. 2005-100. International Monetary Fund. 
Ziaja, Sebastian, 2016, More Donors, More Democracy: The Unintended Blessings of Donor Proliferation, Heidelberg University Discussion Paper.

Ziaja, Sebastian, 2012, What do Fragility Indices Measure? Zeitschrift für Vergleichende Politikwissenschaft 6: 39-64. 